\title{
DOCTOR OF NURSING: CAPACITY FOR BUILDING A PROFESSIONAL AND SCIENTIFIC CAREER PROJECT
}

\author{
Diana Coelho Gomes ${ }^{1}$, Marta Lenise do Prado², Bruna Pedroso Canever³, Bruna Helena de Jesus ${ }^{4}$, Luciara Fabiane \\ Sebold ${ }^{5}$, Vânia Marli Schuberts Backes ${ }^{6}$
}

${ }^{1}$ M.Sc. in nursing. Programa de Pós-graduação em Enfermagem (PEN), Universidade Federal de Santa Catarina (UFSC). Florianópolis, Santa Catarina, Brazil. E-mail: dianacoelhog@yahoo.com.br

2 Ph.D. in nursing. Professor, Departamento de Enfermagem and at PEN/UFSC. CNPq researcher. Florianópolis, Santa Catarina, Brazil. E-mail: marta.lense@ufsc.br

${ }^{3}$ Ph.D. in nursing. Technical supervisor Associação Saúde da Família. São Paulo, São Paulo, Brazil. E-mail: brunacanever@gmail. com.br

${ }^{4}$ M.Sc. in nursing. Nurse, Family Health Strategy of Palhoça City Hall. Palhoça, Santa Catarina, Brazil. E-mail: brunahelena_j@ yahoo.com.br

5 Ph.D. in nursing. Professor, Departamento de Enfermagem, UFSC. Florianópolis, Santa Catarina, Brazil. E-mail: fabisebold@gmail.com

${ }^{6}$ Ph.D. in nursing. Professor, Departamento de Enfermagem, PEN/UFSC. Researcher of CNPq. Florianópolis, Santa Catarina, Brazil. E-mail: vania.backes@ccs.ufsc.br

\begin{abstract}
This was an exploratory and analytical research with a qualitative approach which aimed to understand how newly graduated doctors of nursing built their scientific career projects, considering the eight domains of the Profile of the Doctor of Nursing of the Coordination for the Improvement of Higher Education Personnel Ministry of Education/Brazil. Sixteen graduates of Graduate Nursing Programs in Brazil with grades five, six and seven, graduated between the years 2008-2012, were interviewed. From the data analysis, five categories emerged: starting careers; seeking the stricto sensu education for professors; recognizing professional training; seeking fulfillment and professional development; and planning careers: facing challenges and barriers. It was possible to reflect upon the lives and needs inherent in the preparation of doctors of nursing for employment in the labor market and on the planning of their professional and scientific careers, in addition to identifying factors of suffering and professional dissatisfaction.
\end{abstract}

DESCRIPTORS: Nursing. Education. Professional Training. Professional Competence.

\section{DOUTOR EM ENFERMAGEM: CAPACIDADE DE CONSTRUÇÃO DO PROJETO DE CARREIRA PROFISSIONAL E CIENTÍFICA}

RESUMO: Pesquisa exploratória, analítica, de abordagem qualitativa com o objetivo de compreender como os recém-doutores em Enfermagem constroem seu projeto de carreira científica, considerando o domínio oito do Perfil do Doutor em Enfermagem da Coordenação de Aperfeiçoamento de Pessoal de Nível Superior Ministério da Educação/Brasil. Foram entrevistados 16 egressos do Cursos de Doutorado em Enfermagem do Brasil com conceito cinco, seis e sete, titulados entre os anos de 2008 a 2012. A partir da análise dos dados, surgiram cinco categorias: iniciando a trajetória profissional; buscando a formação stricto sensu para a docência; reconhecendo a formação profissional; buscando a realização e valorização profissional; planejando a carreira: enfrentando desafios e barreiras. Foi possível refletir a respeito das vivências e das necessidades inerentes ao preparo dos doutores em Enfermagem para a inserção no mercado de trabalho e planejamento da sua carreira profissional e científica, além do reconhecimento dos fatores de sofrimento e insatisfação profissional.

DESCRITORES: Enfermagem. Educação. Capacitação profissional. Competência profissional.

\section{DOCTOR EN ENFERMERÍA: CAPACIDAD DE CONSTRUCCIÓN DEL PROYECTO DE CARRERA PROFESIONAL Y CIENTÍFICA}

RESUMEN: Investigación exploratoria, analítica, con enfoque cualitativo con el objetivo de comprender cómo los recién doctores en Enfermería construyen su proyecto de carrera científica, teniendo en cuenta el documento "Perfil del Doctor en Enfermería" de la Coordinación de Capacitación de Personal de Nivel Superior Ministerio de Educación/Brasil. Se entrevistó a 16 egresados del Curso de Doctorado en Enfermería de Brasil, calificados con concepto cinco, seis y siete, titulados entre los años 2008-2012. A partir del análisis de los datos, hubo cinco categorías: empezando su carrera profesional; buscando la formación stricto sensu para la carrera docente; reconociendo la formación profesional; buscando la satisfación y el reconocimiento profesional; planeando su carrera: frente a los retos y barreras. Fue posible reflexionar sobre las vivencias y necesidades inherentes a la preparación de los doctores en Enfermería para la inserción en el mercado de trabajo y la planificación de su carrera profesional y científico, más allá del reconocimiento del sufrimiento y de los factores de insatisfacción profesional.

DESCRIPTORES: Enfermería. Educación. Capacitación Profesional. Competencia Profesional. 


\section{INTRODUCTION}

Nursing is characterized as a specific field of knowledge and a social profession that has been consolidating itself as a science, incorporating technological innovation. The object of this profession is to provide nursing care to humans. ${ }^{1}$

In 2010, in Brazil, nursing represented $60 \%$ of health care professionals in the Unified Health System of the country, with a total of 1.3 million nurses acting decisively in delivering health care to the population. ${ }^{1}$ In 2011 , there were $1,856,683$ nursing professionals subscribed to the Federal Council of Nursing, of which 346,968 were nurses $(18.6 \%) .^{2}$ From the abovementioned contingent, few pursued a PhD education, and in the years between 2007-2012 (six years) 903 doctors of nursing attained their degree.

Improving $\mathrm{PhD}$ education in nursing is a requirement for both teaching staff in higher education institutions and in meeting the demands of assistance in management services and research. ${ }^{1,3}$ This task is the responsibility of Brazilian Graduate Nursing Programs (GNP), which provides the training of highly qualified and productive masters and doctors of nursing. ${ }^{4}$

In Brazil, stricto sensu education in nursing is a process of advancement and improvement, to both increase the numbers of GNP, and increase the knowledge and training of new masters and doctors. ${ }^{3}$ Also other competencies, abilities and domains inherent to PhDs in nursing emerge. The ability to build a scientific career project is one of the eight competencies/abilities and domains expected in the Profile of Doctors of Nursing, designed by the Coordenação de Aperfeiçoamento de Pessoal de Nível Superior (CAPES). ${ }^{5}$ Little is known, however, about the professional careers, motivation for seeking a PhD degree, professional fulfillment and scientific career projects of doctors of nursing.

This study aimed to understand how newly graduated doctors of nursing build their scientific career projects, considering the $8^{\text {th }}$ Domains of the Profile of Doctors of in Nursing of CAPES. ${ }^{5}$

It intended to contribute to the evaluation of training guidelines for the education of researchers/ scientists in nursing and in the consolidation of their scientific career projects. The main evaluators were the very individuals of this study, Ph.D. graduates from GNP.

\section{METHOD}

This was an exploratory analytical study with a qualitative approach. The study was conducted with 16 graduates of Brazilian Graduate Nursing Programs with evaluation concepts of five, six and seven, according to the 2013 triennial evaluation of CAPES, graduated in the five years prior to this research (2008-2012). In this period, 220 doctors of nursing graduated in the GNP studied.

The inclusion criteria were doctors graduated from three Graduate Nursing Programs (GNP a, GNP $b$ and GNP c) who had completed the PhD course with evaluation concept five, six or seven (triennium 2010-2013). These courses were located in different regions of Brazil and the subjects graduated in the five years prior to the study (2008-2012). Exclusion criterion was graduates who did not respond to the contact made by the researcher. The total number of participants was defined by data saturation.

After selection of the GNP, the search for names of graduates and their respective emails was performed, which were obtained from the database of indicators, theses and dissertations of CAPES, whose public domain access is available at: http:/ / conteudoweb.capes.gov.br/conteudoweb/CadernoAvaliacaoServlet. Complete references of theses and dissertations defended by GNP separated by year were found in these databases. From references, curriculums were accessed in the platform Lattes/ $\mathrm{CNPq}$ and emails were obtained using a database of theses and dissertations of higher education institutions, in which they obtained their doctorates, site of the institution and their work on scientific articles.

Data were collected by means of interviews conducted between February and April 2014, using a semi-structured script designed especially for this study and made up of discursive questions. A copy of the document Profile of Doctors of Nursing/ $\mathrm{CAPES}^{5}$ was previously delivered to the respondent, for reading and understanding.

Interviews were conducted in a place chosen by the respondent and for those who were in different regions of Brazil and worldwide, web conference widgets were used. They were recorded in digital archive and later transcribed and then sent for validation by the participants. They lasted 20-68 minutes.

All participants were women, with ages between 32 and 55 years, with an undergraduate degree in nursing. Seven obtained the qualification 
in 2008, two in 2009, three in 2010, three in 2011 and one in 2012. When collecting data, they were in different areas of activity (teaching, health care, health management and educational management) in three different regions of Brazil (South, Southeast and Northeast) and in two foreign countries.

The collected data were organized according to the following steps: data ordination, where interviews were transcribed, with material reading and organization of reports; data classification, where exhaustive repeated reading was conducted, as was the apprehension of relevant structures of central ideas; formation of subject categories; transversal reading of the material regarding matrix of indicators, designed from the eighth domain (table 1) and Profile of Doctors of Nursing/CAPES 5 , seeking to answer the research question and the final analysis: elaboration of the final report. ${ }^{6}$ The matrix in question was submitted to the validation and contribution of experts in the area.

\section{Table 1 - Matrix of indicators of the $8^{\text {th }}$ Domain of the Profile of Doctors of Nursing/CAPES) ${ }^{5}$}

\begin{tabular}{|l|l|}
\hline $8^{\text {th }}$ Domain & Indicators \\
\hline $\begin{array}{l}\text { Ability to build a scientific career project, } \\
\text { considering leadership, insertion, academic }\end{array}$ & $\begin{array}{l}\text { - Participation in committees and directories of associations/scientific so- } \\
\text { cietlass agencies; }\end{array}$ \\
$\begin{array}{l}\text { recognition, time of professional experience, } \\
\text { interest, willingness, personal conditions or }\end{array}$ & - Professional awards/acknowledgements; \\
needs. & - Functional activity currently developed; \\
& - Professional vocation; \\
- Professional fulfillment.
\end{tabular}

The project was submitted to the Etichal Research Committee of the Universidade Federal de Santa Catarina, as recommended by Resolution N. $466 / 12$ of the National Health Council on research involving human subjects, and approved by opinion N. 539.118, CAAE N. 23846614.3.0000.0121. Agreement from the graduates for participation in this research was obtained by signing an informed consent form. Anonymity was kept using alphanumeric identification (E- respondent, following a numeric sequence 1-16).

\section{RESULTS AND DISCUSSIONS}

From data analysis five categories emerged: starting career; seeking stricto sensu education for professors; recognizing professional training; seeking fulfillment and professional development; planning careers: facing challenges and barriers.

\section{Starting career}

Respondents had different careers in nursing before seeking stricto sensu graduate education. There were reports of careers in health care, as seen in the following report: right after graduation, I worked as a nurse in a hospital, but I always kept in touch with my academic advisor of scientific initiation, I was part of a research group and I was becoming interested and willing to continue with a master's degree, $P h D$, and subsequently pursue an academic career (E6).
Other doctors started their careers as nurses, taking on leadership, management and coordinating positions, as in the following report: as soon as I graduated [nursing undergraduate degree], in the next month I was hired by a large hospital, a private hospital and I went straight to ICU. In ICU, after two months, they moved me to a leading position in ICU [...] After four years working in a leading position in ICU, they invited me to the management of the hospital [...] but I was already thinking about a master's degree, a little influenced by my sisters, who already were master's degree students (E1).

The study also showed the first job of a respondent as a coordinator nurse at a research center: $I$ graduated and worked as a coordinator at a research center. Then I started my first specialization [...] At the same time I was at the specialization course in the afternoon, in the morning I was coordinator at the research center of the university (E3).

There were reports of market insertion as a professor at a high school and other higher education institutions: I worked at a nursing technical course as a professor, this was even the first thing I did after I graduated [...] I was a nursing professor for one year and then I started the master's degree (E8).

In the reports of the newly graduated doctors, various areas of work and employability were observed, such as first jobs in health care, teaching, management and research, before they sought stricto sensu qualification and further education. 
In agreement with the statements of the respondents, a study performed with graduates of a graduate nursing course found the insertion of the newly graduated nurses in care and teaching activities at high school and higher education institutions, highlighting the need for permanent education and for the search for professional qualification as fundamental tools for career consolidation. ${ }^{7}$

\section{Seeking stricto sensu education for professors}

Among the many motivations for participants in seeking stricto sensu graduate education, the most important were the desire to become professors in universities, professional development and wage increment.

The wish to pursue an academic career was a reason given by the doctors of nursing as a motivation to seek stricto sensu graduate education, as demonstrated in the following report: I always wanted to teach, so I had to get a PhD, I had no other choice. My option was to get a PhD, because I wanted in the future, to pursue this academic life [...] Because I wanted to be a researcher, I sought to pursuit a PhD, not only the master's degree. I think that the master's degree gives you foundation to start an academic life, but PhD prepares you to be a researcher (E3).

Stricto sensu graduate education is considered a sine qua non factor in starting university teaching, so in aiming for higher education teaching, the search for a graduate degree is understood as mandatory. This is corroborated in a study performed with students, ex-students and professors of the Stricto Sensu Graduate Program in Collective Health of a Brazilian university. It also indicates the wish to start a teaching career in higher education as one of the most important motivating factors for seeking graduate education and in understanding the important role of stricto sensu education and degree in academic insertion. ${ }^{8}$

Motivation for insertion in strict sensu graduate education is perceived in studies, especially, pragmatic ones, with the intention of being able to get into higher education, considering requirements of Law 9.394/96. This law states guidelines and bases for professional education and determines that university teaching staff must be composed of at least $1 / 3$ of masters and doctors. ${ }^{9-10}$

The conviction about nursing with greater visibility and the search for a qualification that provides an opportunity for dialoguing in a respon- sible and competent way with their peers, were also mentioned as a motivation for seeking a doctoral education.

I can say that for two reasons [search for doctoral education]: in the first place because I always believed in a more proactive Nursing, more enterprising, more visionary and with more international visibility. This is a dream that I always had, since I graduated in nursing, and I keep believing and striving for it. In the second place, to see myself in this setting, I thought I should pursuit qualification and a degree, otherwise I would not be able to dialogue in a more responsible and competent way with these interlocutors both national and international. I think that graduate education, not only $\mathrm{PhD}$, but master's degree helped me a lot with it and also post-doctorate now (E1).

Seeking stricto sensu and doctoral education is deeply bound to the search for professional empowerment. A liberating education provides an opportunity for one to reflect about one's own power of thinking and one's own instrumentality. When developing this power and exploring its potentialities, the subject is freed and is empowered in its role in creating a better and more humane society. In this regard, seeking professional qualification through education is a form of freedom and empowerment, building on achievement of actions and changes that promote the evolution and strengthening of the profession. ${ }^{11}$

Another motivation for getting a PhD was related to the development of research, as follows: I started my PhD because of scientific motivation, the wish to research and by far I always wished to be a professor because of the possibility of research, but over the process, I realized that while working in this field it was also possible to do research (E5).

The education of masters and doctors highly qualified for research and for furthering scientific development, is a priority pointed out by GNP and CAPES, as well as for teaching training. Currently, however, education for research is emphasized because of the need for the development of qualified doctors for the requirements of teaching in higher education. ${ }^{12}$

In the reports of the doctors, there is the mention of their aspiration for completing the education, and of their experience in health care having already ignited their expectations. It was something I wanted to accomplish in my education [stricto sensu graduate education]. It could lead me to new professional opportunities, even in my own professional practice, this was 
the reason, and also because I thought that my experience in health care had somehow already contemplated what I expected (E14).

There were reports of the search for qualification for the sake of professional development, career progression and wage increment.

The search for a degree is inherent to the academic life, academic career, for both achieving wage increment and career progression (E4).

My wish to go back to studying is to improve education, seeking a master's degree and a PhD I had two goals: the first, is my education as a professional, nurse and besides better earnings [...] The decision, one of them, that I consider important and that everyone thinks, is academic career, thinking financially [...] Unfortunately in care you do not earn as much (E10).

The wages of a nurse who works in health care is identified as one of the factors of professional dissatisfaction, preceded by precarious labor conditions. ${ }^{13}$ Also lack of appreciation and little autonomy, are also identified as characteristics that cause dissatisfaction in nurses, and make them search for other opportunities. ${ }^{14}$

Seeking academic education is permanently bound to wage increment and career progression, which is in keeping with the logic of a capitalist society, in which there are a predominance of policies that state that workers should be increasingly qualified, productive and generate added value to institutions. Permanent education in the health field facilitates transformation, in that it allows workers to acquire knowledge based on individual and collective freedom and founded on citizenship principles, in which individual professional qualifications can lead to social transformations. ${ }^{15}$

Doctoral education was related to the search for qualification for teaching in universities, to which they were involved before attaining the degree: first, [the wish to become a Ph.D student] $a$ personal interest, I always enjoyed evolving, regarding knowledge, experience, trying work in my profession with the best. Because it is a professional incentive to qualification and I understood that it was necessary for me to work as a professor (E12).

The search for a $\mathrm{PhD}$ qualification meets the need for qualifying as a professor in higher education, identifying the teaching activity as a process that requires the acknowledgment of incompleteness without a $\mathrm{PhD}$. So, the awareness that we are incomplete beings bases the process of permanent education and the search for constant education for professors/ professionals. ${ }^{16}$

The motivation for attaining a $\mathrm{PhD}$ degree was also cited for performing highly qualified professional activity in health care and also for having interests and needs for gaining knowledge in this area: it all began because I entered a very specialized area [...] I started realizing that nurses of the area produced little knowledge, I thought about doing something different [...] I found it interesting to search for improvement, I started master's degree [...] I got my master's degree and I was already preparing myself for PhD (E13).

The search for new knowledge that can result in transformation in professional practice through research is underscored in the thinking of Freire. For this author, there is no teaching without research, and no research without teaching. During research, one questions, verifies, acts and educates oneself. In this process, from what is known and still unknown, findings are communicated and announced, transforming naïve curiosity into epistemological curiosity. ${ }^{16}$

\section{Recognizing professional training}

For some respondents, initial professional training was not undertaken in order to be a professor, however, teaching came about as a consequence of the process of stricto sensu education, as shown in the following report: I never wanted to be a professor. In the first place, I am going to tell you something: something I always had very clear in my life is that I never wanted to be a professor, but my destiny led me to it [...] In fact, I always thought I belonged in management. And teaching, I could say, was some sort of consequence of this process [stricto sensu education] because as soon as I graduated [in PhD] it was one of the opportunities, I received many proposals and I ended up choosing this one. And I did not regret it, I like what I do today (E1).

Graduate education was what determined my choices, making me get where I am today, teaching in the university, because until I finished graduate education, both master's and PhD, I was very focused on the hospital (E6).

The wish to develop research and to be a researcher appeared as a determining factor in professional choices and the pursuit of academic career: I always enjoyed studying. When I decided to start the undergraduate course in nursing, when I read the information of the options of the university, it said that 
nursing developed research, this is why I took nursing, otherwise I would not have taken it, I would have taken another course (E5).

Other reports identified care practice as a motivating factor for seeking pedagogical practice and teaching.

Care combined with teaching is conceived of as inseparable and an intrinsic aspect of the professional practice of a nurse. The interaction between care and education provides for professional development in health in a critical, creative, ethical, political and technical way. Education is considered as a way of caring and care is considered as a way of educating. ${ }^{17}$

Other respondents affirmed that they had the vocation and wish to become professors and they searched for stricto sensu education as a form of consolidating a teaching career: since my third undergraduate term, I already knew I wanted to be a professor [...] I always wanted [to be a professor] [...] I finished my undergraduate education knowing that I wanted to teach. So, all my journey until becoming a professor was not easy, but I already know what I wants. I traced, literally, traced what I wants to do in that time to get where I am [...] I think that this wish came to me because of some professors I had and what I imagined academic life was like (E3).

There were reports in which respondents presented teaching as a vocation, however, first they looked for experience in health care and then they pursued education and a teaching career: It was very clear to me that I could not be a professor if I did not have the experience of doing it, I needed to prioritize health care when I graduated, not being a professor already, in the first place, but I knew I had this vocation, I know that I would be happy with this vocation if I had a lot of experience first in health care practice (E2).

Teaching at a university is a complex profession that requires knowledge of content from the professors. Moreover, teaching is different than the getting an education. Educating requires methodical severity, research, respect of the knowledge of the students, criticality, ethics, reflective criticism about practice, respecting the autonomy of students and awareness of any incompleteness. ${ }^{16}$ Care practice and technical knowledge to the detriment of pedagogical knowledge corroborate banking education principles, in which education is restricted to the domain of concepts and its transmission. Content is an important domain in the process of teaching and learning, however it cannot be considered the principal and single step in it.

\section{Seeking fulfillment and professional development}

Professional fulfillment and development appear in the reports of the respondents who relate both factors with academic development, respect, opportunities and wage increment derived from titration: I think that a person who has a PhD is very respected. When you arrive in a place and they see in your curriculum that you are PhD, the employees, the students, the other colleagues respect you. There is a very strong culture upon the doctor [...] so, I think that this opens doors, respect, if it had to be characterized in a single word it would be respect, I think that we are more respected in the labor market [...] The wage is better, there is a wage difference and opportunities show much more easily, I work less and I earn more (E2).

Awards and invitations to participate in scientific events, examination boards of master's degree and $\mathrm{PhDs}$ and classes on the subject, were as factors cited for academic development and leadership: I have a leadership feeling, in the sense that I always want to be remembered in scientific events of the area, participate in evaluation processes of master's degrees and PhDs in the area [...] Academic development, something I am very proud of is this honorable mention [that I received] in the CAPES thesis award (E13).

The teaching staff are the sculptors of the institutional culture, having a great influence on the implications of the quality of the institution and in the success of the process of teaching and learning. There are many factors that contribute to the dedication and personal satisfaction of the professors at work, such as acceptance by their peers, acceptance by the professors and professional progress, among others. Satisfaction at work is a very important factor for the revitalization and motivation of professors and as a result also for the students. ${ }^{18}$

There were reports in which respondents considered themselves to be professionally partially fulfilled, and this was because they had not yet accomplished all of their goals and plans for their professional careers: I consider myself partially fulfilled. I traced an objective in my life and I made it, I even said that when I was forty years old I wanted to have my PhD and I wanted to be outside the hospital area, the care. In fact, I made it, I defended my PhD before I was forty, I work with research area, I am in the 
hospital setting, but I do not assist patients. Therefore, the only thing that is missing [...] is really getting into the academic area, properly, being bounded to people's education and my dream is to get into a very important university, so I will seek it (E7).

There were reports in which respondents still do not consider themselves fulfilled, relating professional fulfillment with development of expertise, competence and social transformation: I consider myself fulfilled because I was able to get the PhD. I consider myselffulfilled because my goals were achieved, but completely fulfilled, no, because I need to have opportunities to achieve this attractive profile of CAPES, for that we need to have opportunities (E16).

The desire to achieve goals proposed by CAPES and the objectives set for a scientific career were identified as causes for anguish and dissatisfaction by the newly graduated doctors of nursing. The system of organization and operation of CAPES is built in with requirements and productivity goals and a professional profile that is difficult to attain, however, when these goals are achieved, new requirements are imposed. "Hence, no matter what we do, it is not enough, and not achieving goals causes a lot of reprisals resulting in blaming the victim" . ${ }^{19: 452}$

The cycle of goals and requirements becomes unattainable and has consequences for work and life conditions, and for the quality of the knowledge produced. ${ }^{19}$

\section{Planning careers: facing challenges and barriers}

Planning a scientific career was attributed to the wish to become a professor at a public university. Also the wish to please the academy is related to stricto sensu education and to the willingness of being a researcher.

I wish to get out of the hospital setting and enter academic life, however it is a disappointment, because you focus on people who know how to do research and enjoy it only in the academic setting [...] I want to join [the academic] career, I am able to, what is missing is the opportunity to participate in tenders, but I intend to get in, yes, to scientific and academic career, I am preparing myself (E7).

The difficulty of building a scientific career project was identified by doctors, because it was a hard process and a challenge to reconcile the building of a scientific career with personal conditions.
I am planning, even though it is very hard, at least in my opinion [...] developing research, building a good project so that it is approved, to obtain funding, to me it is not [easy] [...] And making this conciliation, which I think is one of the main challenges, that leaves many professionals undecided, to go on or not, it is about conciliating it with time of professional life, interest, willingness, personal needs or conditions, especially personal conditions [...] In my case, now, thinking about where I am today, in the university, where I find myself, the decision that made me stay there and do not try again in the university where I received all of my education, is personal [...] is you think about the development of the doctor's profile, I would have to go back to the university where I graduated, because it is more consolidated (E10).

Another difficulty reported with regard to the building of a scientific career, was related to the lack of public tenders and hiring of substitute professors. I think it is a barrier this construction ability of your scientific career project, it is not even the newly graduated doctor's ability, but the difficulties they find, the barriers that they find in this path [...] We just had state professors' strike, who were pressuring the government for tender, because most of the professors in state university are substitutes, they are precarious professors. The government set a confrontation with professors and still have not discussed the possibility of a tender. There was a promise of strike, but no public notice for tender was released yet (E16).

Some reports considered future planning for professional and scientific careers for the accomplishment of post-doctoral internship, interchanges and greater development research. I consider a possibility of interchange, yes. I think that we have to have projects, at some point we build it (E15).

The development and strengthening of nursing requires education and qualification in preparation for research and leadership. This enables professionals to build a solid career composed of collective professional issues.

\section{FINAL CONSIDERATIONS}

This study was aimed at highlighting the interface of professional careers, the search for stricto sensu education, vocation development, professional performance and recognition and career planning of doctors of nursing. It considered the needs inherent to the preparation of the graduates for insertion into the labor market and to the planning of professional and scientific careers. It also considered the factors 
that caused suffering and professional dissatisfaction in these candidates.

The doctors had different professional careers, and also different motivations emerged in the search for stricto sensu education. Among them were a strong willingness to have a career as a professor/ researcher in higher education institutions, a desire for wage increments and career progression and greater professional development.

The search for a teaching career because of wage increments underscores the professional depreciation of nurses in comparison with other fields. The reports demonstrate university teaching as something desired and as a professional vocation, however, it is also shown as a consequence of the process of stricto sensu qualification and education.

Results demonstrated the interest of the respondents in continuing their research projects and professional development. They considered themselves as incomplete beings searching for improvement for their practices, with development and recognition by their peers. Internationalization appears as an important planning criteria in the consolidation of their scientific careers and personal satisfaction.

It is necessary to emphasize the difficulties, pointed out by doctors regarding the building of their scientific career projects, highlighting personal interests and conditions as factors that impose barriers in these projects. Other barriers cited were lack of public tenders and the hiring of temporary professors in public universities.

\section{REFERENCES}

1. Coordenação de Aperfeiçoamento de Pessoas de Nível Superior (BR). Relatório de avaliação 2007-2009 trienal 2010-área de avaliação: Enfermagem [Internet]. 2010. [cited 2012 Sep 12]. Available from:http:// trienal.capes.gov.br/wp-content/uploads/2010/09/ ENFERMAGEM-rel-11set10.pdf

2. Conselho Federal de Enfermagem (BR). Enfermagem em Dados [Internet]. 2011 [cited 2013 Jun 12]. Available from:http://novo.portalcofen.gov.br/ planejamento-estrategico-2

3. Coordenação de Aperfeiçoamento de Pessoas de Nivel Superior (BR). Documento de Área 2013 [Internet]. 2013 [cited 2014 Jun 18]. Available from:http:// www.capes.gov.br/images/stories/download/ avaliacaotrienal/Docs_de_area/Enfermagem_doc_ area_e_comiss\%C3\%A3o_att08deoutubro.pdf
4. Erdmann AL, Fernandes JD, Lunardi VL, Robazzi MLC, Rodrigues RAP. O alcance da excelência por Programas brasileiros de Pós-Graduação stricto sensu com Doutorado em Enfermagem. Texto Contexto Enferm [Internet]. 2012 [cited 2014 Jun 18]; 21(1):130-9. Available from: http:/ / www.scielo.br/scielo.php? script $=$ sci $_{-}$ arttext\&pid=S0104-07072012000100015

5. Coordenação de Aperfeiçoamento de Pessoas de Nível Superior (BR). Relatório de avaliação 2007-2009 Trienal 2010- Área de Avaliação: Enfermagem [Internet]. 2010 [cited 2012 Sep 12]. Available from: http:// trienal.capes.gov.br/wp-content/uploads/2010/09/ ENFERMAGEM-rel-11set10.pdf

6. Minayo MCS. O desafio do conhecimento: pesquisa qualitativa em saúde. 12a ed. São Paulo: Hucitec; 2010.

7. Jesus BH, Gomes DC, Spillere LBB, Prado ML do, Canver BP. Inserção no mercado de trabalho: trajetória de egressos de um curso de graduação em enfermagem. Anna Nery Enferm. 2013; 17(2):336-45.

8. Ribeiro ML, Cunha MI. Trajetórias da docência universitária em um programa de pós-graduação em Saúde Coletiva. Interface - Comunic, Saude, Educ. 2010; 14(32):55-68.

9. Soares SR, Cunha MI. Formação do professor: a docência universitária em busca de legitimidade. Salvador (BA): EDUFBA; 2010.

10. Brasil. Lei 9.394/1996: estabelece as diretrizes e bases da educação nacional. Diário Oficial da República Federativa do Brasil, 20 Dez 1996.

11. Freire P. Educação como prática da liberdade. $34^{\mathrm{a}} \mathrm{ed}$. Rio de Janeiro: Paz e Terra; 2011.

12. Pimentel V, Mota DDCF, Kimura M. Reflexões sobre o preparo para a docência na pós-graduação em enfermagem. Rev Esc Enferm USP. 2007; 41(1):161-4.

13. Batista AAV, Vieira MJ, Cardoso NC dos SC, Carvalho GRP de. Fatores de motivação e insatisfação no trabalho do enfermeiro. Rev Esc Enferm USP. 2005; 39(1):85-91.

14. Amestoy SC, Cestari ME, Thofehrn MB, Milbrath VM, Porto AR. Características institucionais que interferem na liderança do enfermeiro. Rev Gaúcha Enferm. 2009; 30(2):214-20.

15. Silva LAA, Ferraz F, Lino MM, Backes VMS, Schmidt SMS. Educação permanente em saúde e no trabalho de enfermagem: perspectiva de uma práxis transformadora. Rev Gaúcha Enferm. 2010; 31(3):557-61.

16. Freire P. Pedagogia da autonomia: saberes necessários à prática educativa. $43^{\mathrm{a}}$ ed. Rio de Janeiro: Paz e Terra; 2011.

17. Ferraz F, Silva LWS, Silva LAA, Reibnitz KS, Backes VMS. Cuidar-educando em enfermagem: passaporte para o aprender/educar/cuidar em saúde. Rev Bras Enferm. 2005; 58(5):607-10. 
18. Machado ML, Soares VM, Ferreira JF, Gouveia O. Satisfação e motivação no trabalho: um estudo sobre os docentes do Ensino Superior em Portugal. Rev Port Pedagog. 2012; 46(1):95-108.
19. Bianchetti L. Condições de trabalho e repercussões pessoais e profissionais dos envolvidos com a pósgraduação stricto sensu: balanço e perspectivas. Linhas Crít. 2011; 17(34):439-60. 